\title{
Measles outbreak: preliminary report on a case series of the first 8,070 suspected cases, Manaus, Amazonas state, Brazil, February to November 2018
}

Guilherme Almeida Elidio ${ }^{1}$, Giovanny Vinícius Araújo de França ${ }^{1}$, Flávia Caselli Pacheco ${ }^{1}$, Marinélia Martins Ferreira² ${ }^{2}$ Jair dos

Santos Pinheiro ${ }^{2}$, Eliane Nogueira Campos², Bernardino Cláudio de Albuquerque 3 , Rosemary Costa Pinto ${ }^{3}$, Angela Desiree Carepa

Santos da Silva ${ }^{3}$, Priscila Leal e Leite ${ }^{1}$, Greice Madeleine Ikeda do Carmo ${ }^{1}$, Andre Luiz de Abreu ${ }^{1}$, Cintia Paula Vieira Carrero ${ }^{1}$,

Marli Rocha de Abreu ${ }^{1}$, Fabiano Marques Rosa ${ }^{1}$, Cesar M. de Oliveira ${ }^{4}$, Dirce Bellezi Guilhem ${ }^{5}$

1. Secretariat of Health Surveillance, Ministry of Health, Brasília, Brazil

2. Municipal Health Secretariat of Manaus, Amazonas, Brazil

3. Fundação de Vigilância em Saúde do Estado do Amazonas, Manaus, Brazil

4. Department of Epidemiology \& Public Health, University College London, London, UK

5. Post-Graduation Program in Health Sciences, University of Brasília, Brasília, Brazil

Correspondence: Guilherme Almeida Elidio (guilherme.elidio@saude.gov.br)

Citation style for this article:

Elidio Guilherme Almeida, França Giovanny Vinícius Araújo de, Pacheco Flávia Caselli, Ferreira Marinélia Martins, Pinheiro Jair dos Santos, Campos Eliane

Nogueira, Cláudio de Albuquerque Bernardino, Pinto Rosemary Costa, Santos da Silva Angela Desiree Carepa, Leal e Leite Priscila, do Carmo Greice Madeleine

Ikeda, Luiz de Abreu Andre, Carrero Cintia Paula Vieira, Rocha de Abreu Marli, Rosa Fabiano Marques, de Oliveira Cesar M., Guilhem Dirce Bellezi. Measles

outbreak: preliminary report on a case series of the first 8,070 suspected cases, Manaus, Amazonas state, Brazil, February to November 2018 . Euro Surveill.

2019;24(2):pii=1800663. https://doi.org/10.2807/1560-7917.ES.2019.24.2.1800663

We report an ongoing measles outbreak in Manaus, Amazonas state, Brazil. As at 3 November 2018, 1,631 cases were confirmed corresponding to an incidence of 75.3 per 100,000 inhabitants; all five sanitary districts presented confirmed cases. Reintroduction of measles virus in Manaus is likely related to the current outbreak in Venezuela and due to recent decline in measles vaccine coverage. Given the current scenario, prevention and control measures should target individuals aged $15^{-29}$ years.

In February 2018, a measles outbreak was reported in the state of Roraima, Brazil and was found to be associated with the ongoing measles outbreak in Venezuela [1]. As at 10 December 2018, 349 cases have been confirmed [2]. Between 2001 and 2017, the Amazonas state did not report any confirmed measles cases [3]. Here, we report the ongoing measles outbreak in Manaus capital of the Amazonas state in Brazil. The north of Amazonas state borders Venezuela. Manaus has 2,145,444 inhabitants.

\section{Case definition, laboratory testing and investigations}

In 1969, the Ministry of Health $(\mathrm{MoH})$ in Brazil established that all suspected measles cases seeking health services must be notified to the local authorities; cases must also be registered in the National System of Notifiable Diseases (Sinan) [4]. In addition, an ad hoc system known as 'TRACK' was made available in Manaus during the epidemiological week (EW) 19 (starting on 12 May 2018) to track register all data collected in the health services and through interviews in the present outbreak. In this study, we included all cases registered in TRACK until 3 November 2018 who lived in Manaus and met the suspected case definition (Box) [5-7].

In Brazil, all samples processed by the public health laboratory network are registered in the Laboratory Environment Management System (GAL); test results obtained in the ongoing outbreak available in GAL were also registered in TRACK to support case classification. The epidemiological and laboratory investigations, as well as contact tracing, were conducted by the Secretariat of Health of the municipality of Manaus, together with the Amazonas State Health Secretariat and the Brazilian $\mathrm{MoH}$. All samples were sent to the National Reference Laboratory at the Oswaldo Cruz Foundation (Fiocruz) in Rio de Janeiro. Those who met the clinical criteria and presented laboratory confirmation were considered as 'confirmed'.

\section{Outbreak onset}

The first laboratory confirmed case of the ongoing outbreak was a woman in her early 20 s living in the northern district of Manaus. She had rash onset on 21 February 2018 and presented with fever, cough, coryza and conjunctivitis. She was identified during the investigation of her one-year old child's case who had rash onset on 1 March and presented the same symptoms as the mother. Laboratory confirmation of measles was obtained on 23 March 2018.

The D8 genotype measles virus was identified in a urine sample from the infant, which was identical to 
Definition of cases and other categories followed-up during the measles outbreak, Manaus, Amazonas, Brazil, 2018

Suspected case:
- Any person in whom a health professional suspects measles infection; or
- Any person with fever and maculopapular rash (i.e. non-vesicular) and cough, coryza (i.e. runny nose) or conjunctivitis (i.e. red eyes);
or

- Any person with a history of travel to sites with measles virus circulation in the last 30 days, or who has had contact in the past 30 days with someone who has travelled to sites with viral circulation.

\section{Confirmed case:}

Laboratory: A case that meets the clinical case definition and has laboratory-confirmation of measles virus infection:

- A positive serologic test for measles immunoglobulin M antibody; or

- Isolation of measles virus from a clinical specimen; or

- Detection of measles-virus specific nucleic acid from a clinical specimen using polymerase chain reaction; or

- IgG seroconversion or a significant rise in measles immunoglobulin $\mathrm{G}$ antibody using any evaluated and validated method.

Epidemiologically: A case that meets the clinical case definition and has contact with a laboratory-confirmed measles case whose rash onset was within the preceding 21 days, or a case that lives in the same district or adjacent districts where a measles outbreak has been laboratory- confirmed and transmission is plausible.

\section{Discarded case:}

A suspected case, which, upon adequate investigation that includes a blood specimen collected in the appropriate time frame, lacks serologic evidence of a measles virus infection.

the one that is circulating in Venezuela; genotyping also showed that it was a wild-type measles virus. The mother reported having had contact with three Venezuelan migrants in January 2018, whom were interviewed by the surveillance team; one of them presented with malaise, diarrhoea, high fever and redness in the body soon after arriving in Manaus, but denied having presented with measles rash. None of the migrants had a history of vaccination against measles. The migrants did not match the case definition for notification and were identified retrospectively, 40 days after their symptom onset, therefore, laboratory tests were not carried out as too much time had elapsed. The infant did not have contact with the migrants during the incubation period; the only contacts were the mother and father, and the latter had been vaccinated against measles. Therefore, the probable source of infection of the infant was the mother.

Although the current available information suggest a link between the outbreaks in Venezuela and Manaus, further molecular epidemiological studies are needed to help understanding the reintroduction of measles in the municipality.

\section{Epidemiological situation}

From 6 February-3 November 2018, 8,070 suspected cases were notified; of these, 5,971 (74.0\%) were still under investigation. Among the cases with complete investigation, $1,631 \quad(77.7 \%)$ were confirmed and 468 (22.3\%) were discarded; the median interval between the date of notification and the date of the final classification of the case was 37 days (range 0-140 days). All the confirmed cases were Brazilians. The incidence of measles among confirmed cases was 75.3 per 100,000 inhabitants; the incidence was higher among infants (1,003.9/100,000 inhabitants) and children aged $1-4$ years (175.3/100,000 inhabitants). Up to 3 November, the northern district accounted for the largest number of cases (2,753 cases) (Table 1$)$.

The epidemic curve shows a gradual increase in the number of cases with symptom onset from 6 May, reaching a peak of 763 cases in EW 29 (15-21 July), then decreasing gradually (Figure 1). The median reporting delay was 1 day (range 0-155 days), considering the difference between the notification and rash onset dates; therefore, the decrease in the number of notifications from the EW 30 onwards does not seem to be explained by the reporting delay. All five districts presented confirmed cases, which indicates the circulation of the virus throughout the municipality (Figure 2).

Of 7,602 notified cases, the majority (55.5\%) were male; among women, 86 of $3,385(2.5 \%)$ were pregnant. The age group with the highest number of cases (26.6\%) was the 20-29-year-olds, followed by those aged 15-19 years (23.3\%). Together, these two age groups comprised ca $50 \%$ of all notifications (Table 1 ). Up to week EW 22, most cases were in the age group of 6 months -4 years, from the EW 23 onwards, however, an increase of cases aged 15-29 years was observed (Figure 3A). 
TABLE 1

Key features of reported and confirmed measles cases, Manaus, Amazonas state, Brazil, 6 February-3 November 2018

\begin{tabular}{|c|c|c|c|c|c|c|}
\hline \multirow[t]{2}{*}{ Variable } & \multicolumn{3}{|c|}{ 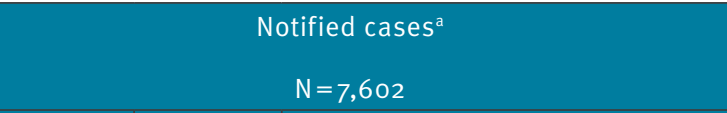 } & \multicolumn{3}{|r|}{$\begin{array}{l}\text { Confirmed cases } \\
\qquad N=1,631\end{array}$} \\
\hline & $\mathrm{n}$ & $\%$ & Incidence per 100,000 inhabitants & $\mathrm{n}$ & $\%$ & Incidence per 100,000 inhabitants \\
\hline \multicolumn{7}{|l|}{ Sanitary district } \\
\hline East & 2,454 & 32.3 & 460.1 & 525 & 32.2 & 98.4 \\
\hline North & 2,753 & 36.2 & 461.5 & 506 & 31.0 & 84.8 \\
\hline West & 1,011 & 13.3 & 211.3 & 290 & 17.8 & 60.6 \\
\hline South & 1,325 & 17.4 & 253.4 & 270 & 16.6 & 51.6 \\
\hline Rural & 59 & 0.8 & 418.2 & 40 & 2.5 & 283.5 \\
\hline \multicolumn{7}{|l|}{ Sex } \\
\hline Female & 3,385 & 44.5 & 355.2 & 755 & 46.3 & 79.2 \\
\hline Male & 4,217 & 55.5 & 463.9 & 876 & 53.7 & 96.4 \\
\hline \multicolumn{7}{|l|}{ Age group } \\
\hline$<6$ months & 549 & 7.2 & $2828.6^{b}$ & 203 & 12.5 & $1003.9^{b}$ \\
\hline 6-11.9 months & 578 & 7.6 & $2828.6^{b}$ & 197 & 12.1 & $1003.9^{b}$ \\
\hline $1-4$ years & 746 & 9.8 & 489.9 & 267 & 16.4 & $175 \cdot 3$ \\
\hline $5-9$ years & 314 & 4.1 & 160.1 & 100 & 6.1 & 51.0 \\
\hline $10-14$ years & 355 & $4 \cdot 7$ & 166.3 & 116 & 7.1 & 54.4 \\
\hline $15-19$ years & 1,770 & 23.3 & 853.1 & 225 & 13.8 & 108.4 \\
\hline $20-29$ years & 2,021 & 26.6 & 467.3 & 332 & 20.4 & 76.8 \\
\hline $30-39$ years & 830 & 10.9 & 229.0 & 101 & 6.2 & 27.9 \\
\hline $40-49$ years & 319 & 4.2 & 113.8 & 61 & 3.7 & 21.8 \\
\hline $50+$ years & 120 & 1.6 & 42.8 & 29 & 1.8 & 10.3 \\
\hline \multicolumn{7}{|l|}{ Pregnancy } \\
\hline No & 3,299 & 97.5 & NA & 744 & 98.5 & NA \\
\hline Yes & 86 & 2.5 & NA & 11 & 1.5 & NA \\
\hline \multicolumn{7}{|c|}{ Admitted to hospital } \\
\hline No & 6,289 & 88.4 & NA & 1,164 & 71.9 & NA \\
\hline Yes & 823 & 11.6 & NA & 455 & 28.1 & NA \\
\hline \multicolumn{7}{|c|}{ Vaccination status } \\
\hline No & 5,411 & 75.0 & NA & 1,288 & 82.9 & NA \\
\hline Yes & 1,801 & 25.0 & NA & 265 & 17.1 & NA \\
\hline \multicolumn{7}{|c|}{ Signs and symptoms } \\
\hline \multicolumn{7}{|l|}{ Cough } \\
\hline No & 494 & 6.5 & NA & 48 & 2.9 & NA \\
\hline Yes & 7,101 & 93.5 & NA & 1582 & 97.1 & NA \\
\hline \multicolumn{7}{|l|}{ Coryza } \\
\hline No & 1,773 & 23.4 & NA & 235 & 14.4 & NA \\
\hline Yes & 5,809 & 76.6 & NA & 1,393 & 85.6 & NA \\
\hline \multicolumn{7}{|l|}{ Conjunctivitis } \\
\hline No & 3,188 & 42 & NA & 509 & 31.4 & NA \\
\hline Yes & 4,385 & 58 & NA & 1,114 & 68.6 & NA \\
\hline
\end{tabular}

NA: not applicable.

a Includes confirmed cases and those under investigation.

${ }^{\mathrm{b}}$ Incidence based on all infants $<1$ year.

Source: Municipal Health Secretariat of Manaus, Amazonas, Brazil. Data extracted on 6 November 2018. 
Distribution of reported cases of measles according to the epidemiological week of onset of symptoms and investigation status, Manaus, Amazonas state, Brazil, 6 February-3 November 2018

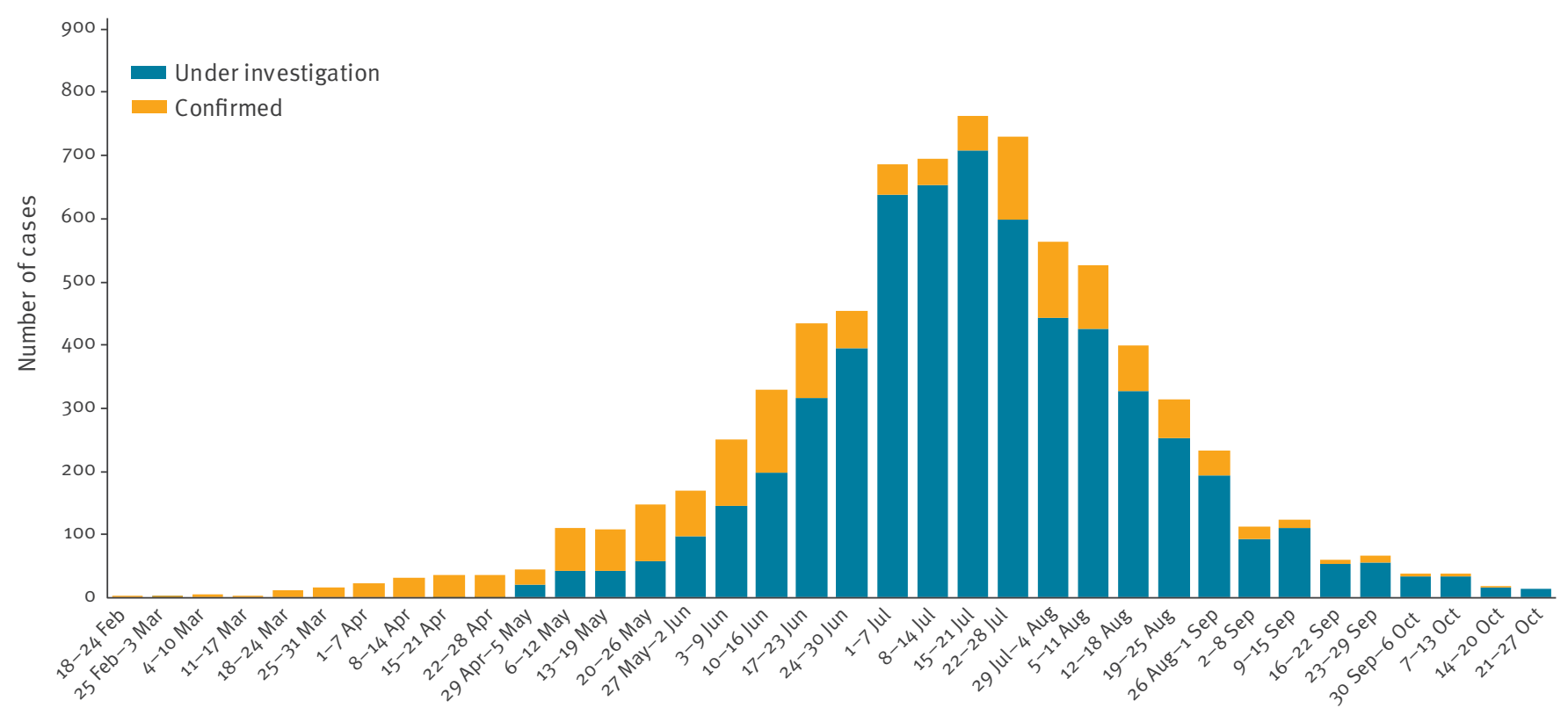

Epidemiological week of rash onset, 2018

Source: Municipal Health Secretariat of Manaus, Amazonas, Brazil. Data extracted on 6 November 2018.

Of 7,212 suspected cases, $75.0 \%$ had no records of vaccination against measles; the percentage was even higher among confirmed cases (82.9\%) (Table 1). In addition, the majority of unvaccinated cases were in the age group of 15-29 years (Figure 3B).

Of the 7,602 suspected cases, 823 (11.6\%) were hospitalised, and the average of the hospitalisation period was 4 days (Table 1). As of EW 29, two measles-related deaths had been recorded in the municipality of Manaus, both in male infants, aged 1 year or younger, below the age recommended for the first dose of measles vaccine, with no comorbidity; the D8 genotype was identified in one of the children and the other one is still awaiting genotyping.

\section{Brazil vaccination schedule}

MCV has been available free of charge in Brazil since 1967; currently, routine vaccination follows the calendar established by the $\mathrm{MoH}$ : one dose of measles, mumps, rubella (MMR) vaccine administered at 12 months of age; one dose of tetravalent vaccine against measles, mumps, rubella, varicella (MMRV) at 15 months; two doses of MMR between 2-29 years of age; and one dose of MMR from 30-49 years of age $[4,8]$.

Official data from the $\mathrm{MoH}$ indicate that the coverage of the first dose of MMR vaccine at 12 months of age decreased markedly in Manaus between 2014 and 2017 (105.7\% vs $81.0 \%$ ); the same pattern was observed for the second dose of the vaccine at 15 months of age in the same period (95.8\% vs $67.0 \%$ ) [9]. It is noteworthy that vaccination coverage in Brazil is obtained through an administrative method [10]; a coverage above $100 \%$ indicates that the number of doses administered in the municipality is greater than the number of residents in a specific age group and time period.

\section{Control measures}

The management of the outbreak have been overseen by the $\mathrm{MoH}$ and coordinated by the local authorities. A situation room was established in Manaus in March 2018 , in order to facilitate the coordination of all strategies for outbreak control and prevention. Since its creation, at least two deliberative meetings have been held weekly.

To date, several strategies have been adopted to interrupt the outbreak. Suspected cases have been investigated within 48 hours, searching for the source of infection and possible secondary cases. Extensive contact tracing for all measles cases has been conducted, verifying the immunisation status of contacts and vaccinating susceptible contacts within 72 hours. Self-isolation post exposure was also recommended. The epidemiological surveillance has been intensified through active and retrospective institutional case finding, including the identification of chains of transmission in the municipality. Initially, the local authorities requested immediate isolation of any suspected cases 
Spatial distribution of reported cases of measles according to investigation status, Manaus, Amazonas state, Brazil, 6 February-3 November 2018

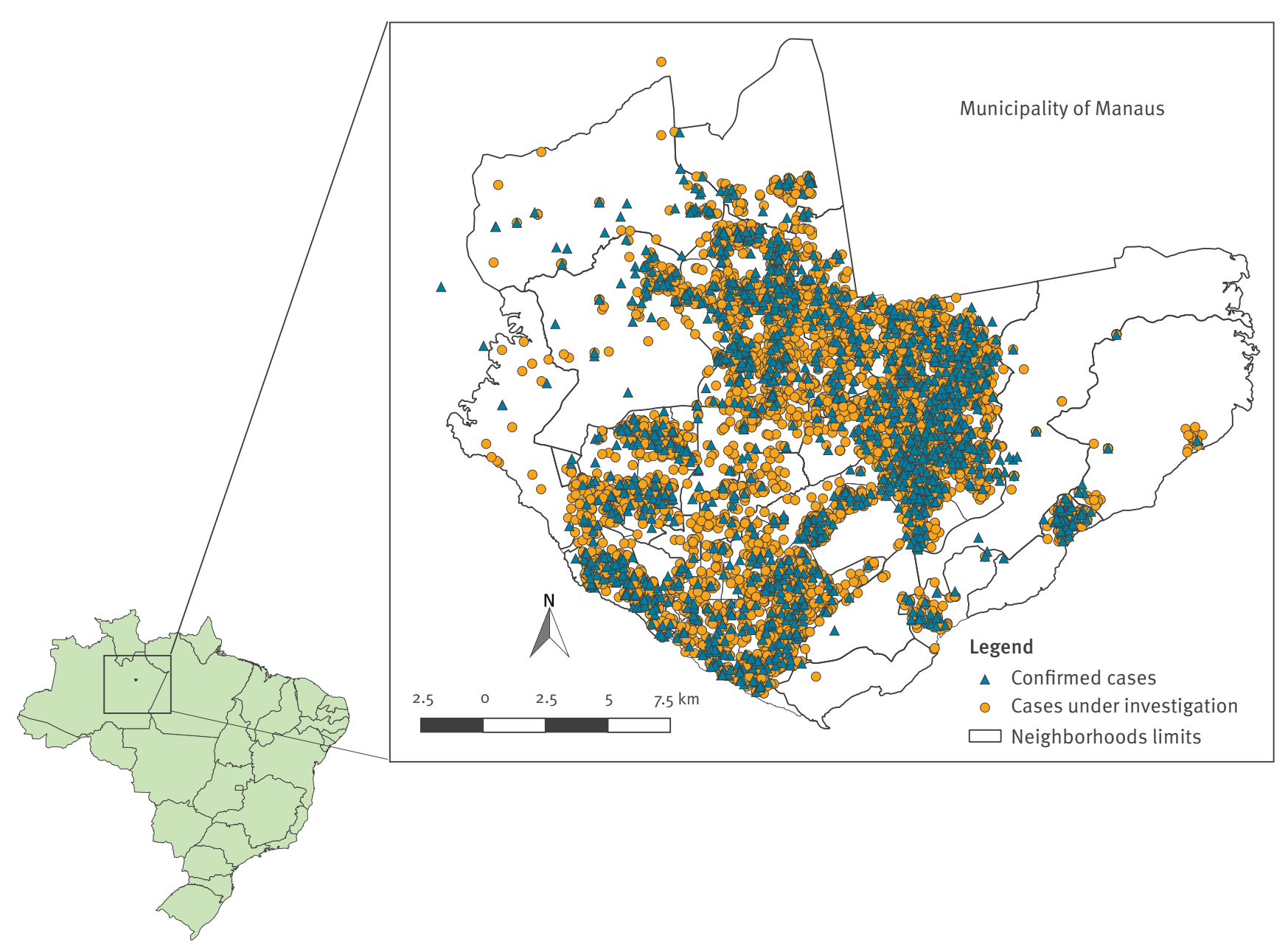

Source: Municipal Health Secretariat of Manaus, Amazonas, Brazil. Data extracted on 6 November 2018.

in reference hospitals. As the number of suspected cases increased substantially over time, hospitalisation became restricted to patients with complications given the limited availability of hospital beds.

Routine vaccination has been intensified in Manaus, free of charge for individuals aged 12 months-49 years. The vaccination campaign was anticipated, targeting children aged 12 months -5 years. It was conducted from 14-27 April 2018, and reached a coverage of more than $95 \%$ according to preliminary data provided by the $\mathrm{MoH}$ [11]. A national campaign was carried out from 6 August-31 October 2018, targeting individuals aged 12 months -5 years. Health professionals were hired and trained in case management and those with no record of vaccination against measles were vaccinated.

The laboratory network was strengthened, ensuring that samples were received at the reference laboratory within 5 days of collection. A risk communication strategy was implemented and media messages were disseminated, aiming to encourage vaccination when appropriate and advising the general population of the symptoms suggestive of measles. Epidemiological reports were made available weekly at the $\mathrm{MoH}$ webpage [12], as well as technical notes with guidelines on flows for epidemiological surveillance, laboratory and immunisation.

\section{Discussion}

The concentration of cases in children aged 5 years and under at the beginning of the outbreak seems to be related to a recent decrease in the coverage of measlescontaining vaccines in Manaus, which may have led to a marked increase in the number of individuals susceptible to the disease in this age group. Consequently, this favoured the reintroduction of the virus in the municipality. In this context, the national vaccination 


\section{FIGURE 3}

Proportional distribution of reported cases of measles according to age group, stratified by (A) epidemiological week of notification and (B) vaccination status ${ }^{\mathrm{a}}$, Manaus, Amazonas, Brazil, 6 February-3 November 2018

\section{A. Reported cases of measles by epidemiological week of notification}

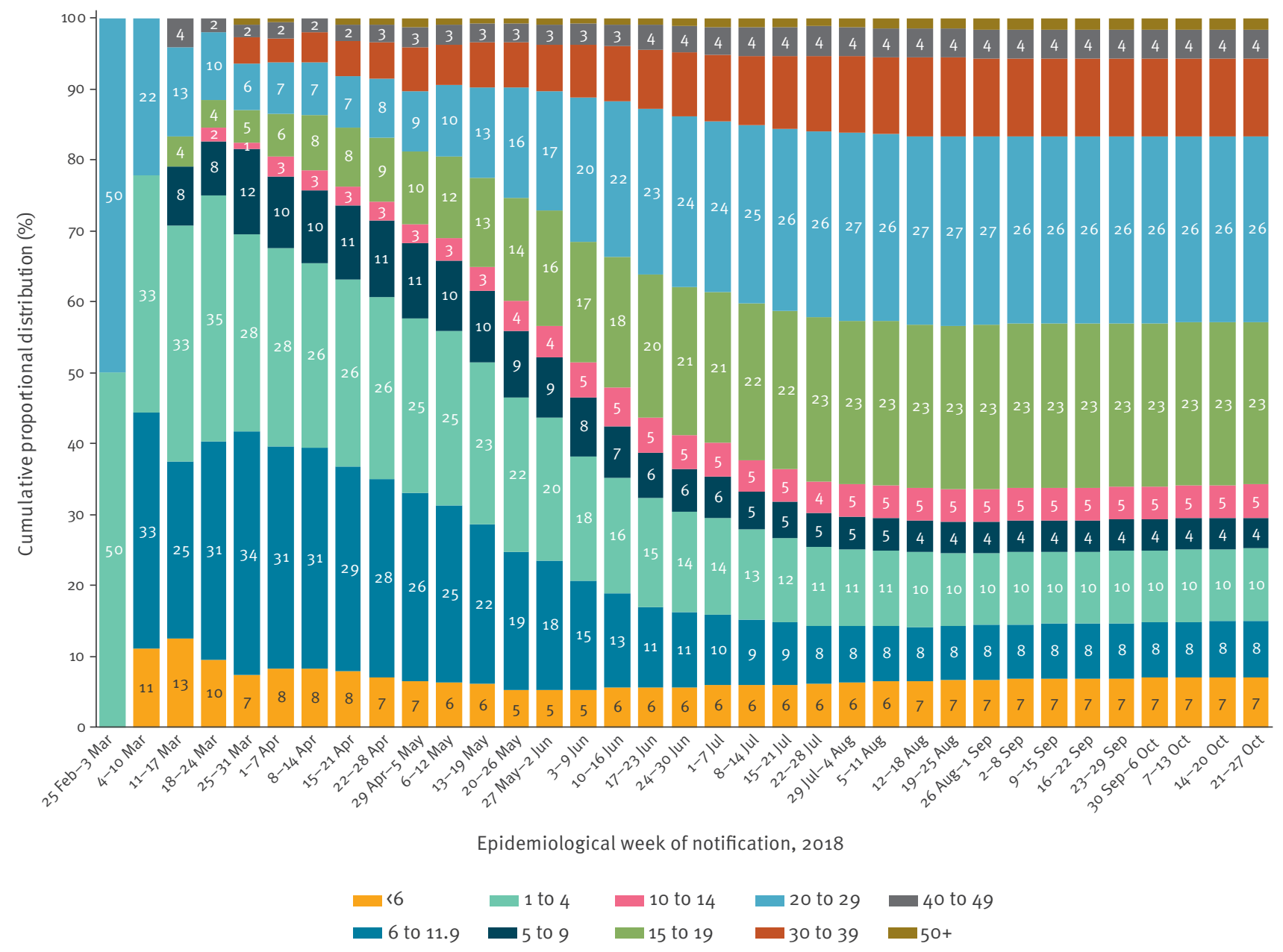

\section{B. Reported cases of measles by vaccination status}

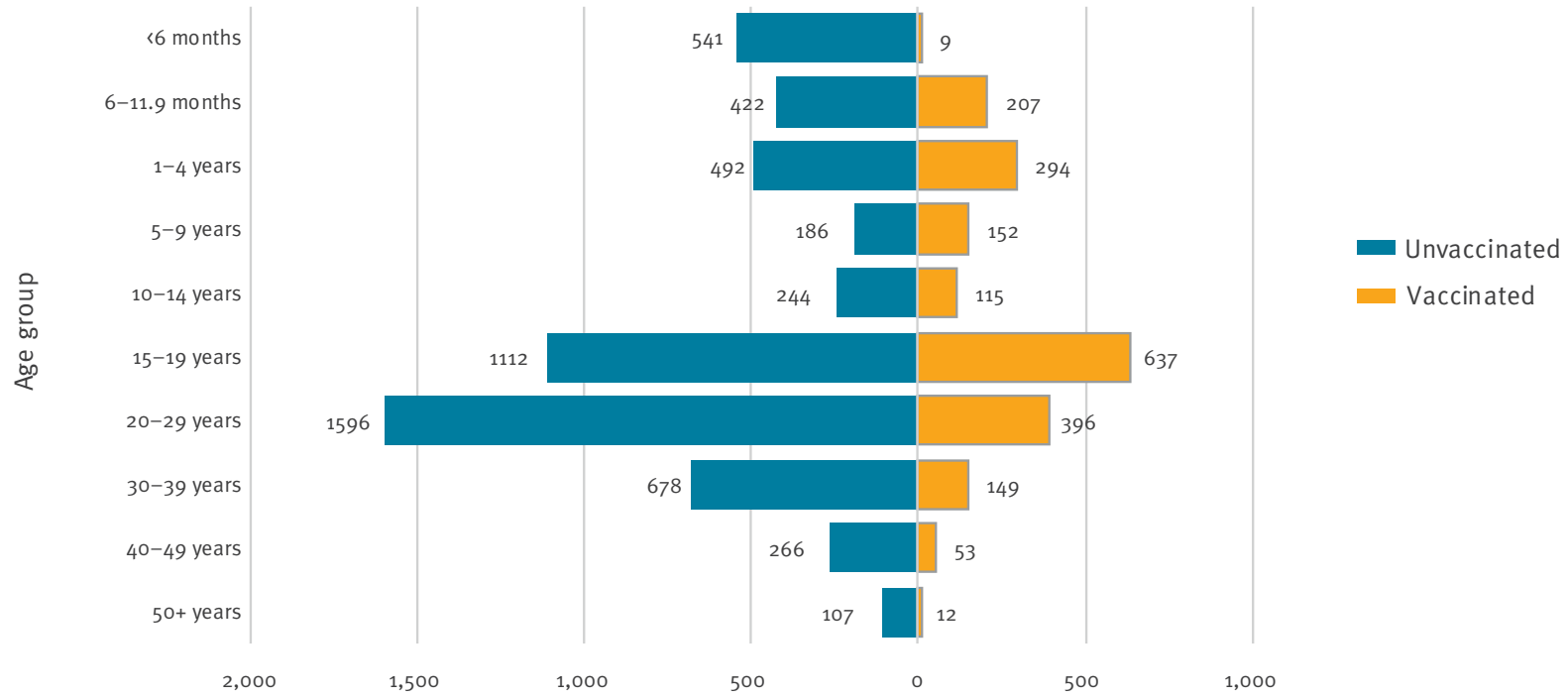

MMR: measles, mumps, rubella; MMRV: measles, mumps, rubella, varicella.

a Vaccination status is based on the calendar for national routine immunisation established by the Brazilian Ministry of Health, as follows: one dose of MMR vaccine administered at 12 months of age; one dose of tetravalent vaccine against MMRV at 15 months; two doses of MMR between $2-29$ years of age; and one dose of MMR from 30-49 years of age.

Source: Municipal Health Secretariat of Manaus, Amazonas, Brazil. Data extracted on 6 November 2018. 
campaign targeting children aged 6 months -5 years seems to have been effective in controlling the spread of the virus in this age group. There was a change in the age distribution of the cases as the outbreak continued where more individuals aged 15-29 years were affected and the available data indicates that most of these individuals had no history of measles vaccination. As our findings are based on preliminary data, these observations should be further investigated in the future.

We acknowledge some limitations of our study. First, due to the magnitude of the outbreak it was not possible to carry out laboratory tests for all cases and most of the cases are still under investigation. Due to this, we opted to present the distributions of both notified and confirmed cases. In addition, there is need to consider the epidemiological link for case classification in future studies [13].

Second, it was not possible to collect detailed vaccination histories to analyse, as surveillance teams only recorded whether an individual had been vaccinated with MMR and if so, the date of the last dose.

Our findings highlight the need to increase the awareness among health professionals so that they can better recognise and report suspected cases of measles. In addition, epidemiological surveillance for timely investigation of cases could be strengthened, as well as better identification of likely sources of infection and secondary cases. Furthermore, given the potential number of susceptible individuals in all age groups, it is essential to intensify routine vaccination efforts and to implement catch-up vaccination, especially for those individuals aged 15-29 years. At national level, the risk of spread in Brazil is high, taking into account the transmissibility of the disease and the performance of the routine immunisation programme. At the regional level, the potential impact is also considered high given the prevention and control capacities in other countries in the Region of the Americas $[14,15]$. Efforts made in recent years to eliminate measles in Brazil may be compromised if effective measures are not taken to stop the transmission of the virus in the northern region of the country.

\section{Acknowledgements}

We gratefully acknowledge the contribution of colleagues from the Health Surveillance Foundation of Amazonas (FVSAM) and the Municipality of Manaus involved in outbreak investigation and reporting of suspected cases to the national surveillance system, especially Isabel Cristina Hernandes. We also thank the staff of the Brazil Ministry of Health and the Brazil Field Epidemiology Training Program (EpiSUS), especially Flávia Cardoso de Melo, for their support in the field investigations, and the international support provided by the Pan American Health Organization (PAHO/WHO). The authors wish to express their special thanks to Renato Vieira Alves for critically reading the manuscript and helpful discussion.
Conflict of interest

None declared.

Authors' contributions

GAE, GVAF and FCP conceived the study design, led the data analyses, drafted the initial manuscript and invited comments from the wider authors.

MMF, JSP, BCA, RCP, ADCSS, PLL, GMIC, ALA coordinated outbreak control and investigation activities.

GAE, ENC, CPVC, MRA, FMR performed the epidemiological investigation.

CMO and DBG supervised and oversaw the manuscript production process.

Each author contributed to the content of the report and participated in drafting and revising the manuscript.

\section{References}

1. Ministry of Health $(\mathrm{MoH})$. Brazil. Informe $n^{0} \mathbf{2 6 / 2 0 1 8}$ - Situação do Sarampo no Brasil - 2018. [Epidemiological Update Measles in Brazil, 2018]. Brasília: MoH; 2018. Portuguese. Available from: http://portalarquivos2.saude.gov.br/images/pdf/2018/ outubro/10/informe-sarampo-26-9out18.pdf

2. Ministry of health $(\mathrm{MoH})$. Brazil. Situação do Sarampo no Brasil - 2018 [Status of Measles in Brazil - 2018]. Brasília: MoH; 2018. Portuguese. Available from: http://portalarquivos2 saude.gov.br/images/pdf/2018/dezembro/14/InformeSarampo-n34-12dez18.pdf

3. Ministry of Health (MoH). Brazil. Confirmed cases of measles. Brazil, major regions and federal units, 1990 to 2018. Brasília: $\mathrm{MoH} ; 2018$. Available from: http://portalarquivos2.saude.gov. br/images/pdf/2018/abril/25/Casos-confirmados-sarampo.pdf

4. Ministry of Health $(\mathrm{MoH})$. Brazil. National Immunization Program (NIP): 40 years. Brasília: $\mathrm{MoH} ; 2013$. Available from: http://bvsms.saude.gov.br/bvs/publicacoes/programa nacional_imunizacoes_pni40.pdf

5. World Health Organization (WHO). Response to measles outbreaks in measles mortality reduction setting. WHO IB/09/03. P5. Geneva: WHO; 2009. Available from: http://apps. who.int/iris/bitstream/handle/10665/70047/WHO_IVB_09.03_ eng.pdf?sequence $=1$

6. Ministry of Health $(\mathrm{MoH})$. Brazil. Guia de Vigilância em Saúde. [Guide to Health Surveillance]. Brasília: MoH; 2017. Available at: http://portalarquivos.saude.gov.br/images/pdf/2017/ outubro/06/Volume-Unico-2017.pdf

7. Centers for Disease Control and Prevention (CDC). Manual for the surveillance of Vaccine-Preventable Diseases. Chapter 7: Measles. Atlanta: CDC; 2018. Available from: https://www.cdc. gov/vaccines/pubs/surv-manual/chpto7-measles.html

8. Ministry of Health $(\mathrm{MoH})$. Brazil. Nota informativa $n^{\circ} 384$, de 2016. Sobre mudanças no calendário nacional de vacinação para o ano de 2017. [Informative note $n^{\circ} 384$, of 2016. About changes in the national vaccination calendar for the year 2017]. Brasília: $\mathrm{MoH}$; 2017. Portuguese. Available from: http:// portalarquivos.saude.gov.br/images/pdf/2016/dezembro/28/ Nota-Informativa-384-Calendario-Nacional-de-Vacinacao-2017. pdf

9. Ministry of Health $(\mathrm{MoH})$. Brazil. National Immunization Program Information System (SIPNI) Brasília: MoH; 2018. Available from: http://sipni.datasus.gov.br/si-pni-web/faces/ relatorio/consolidado/dosesAplicadasMensal.jsf.

10. Domingues CMAS. Teixeira AMdS. Vaccination coverage and impact on vaccine-preventable diseases in Brazil between 1982 and 2012: National Immunization Program progress and challenges. Epidemiol Serv Saúde.2013;22(1):9-27. https://doi. org/10.5123/S1679-49742013000100002

11. Ministry of Health $(\mathrm{MoH})$. Brazil. Situação do Sarampo no Brasil - 2018 [Status of Measles in Brazil - 2018]. Brasília: MoH; 2018. Portuguese. Available from: http:// portalarquivos2.saude.gov.br/images/pdf/2018/outubro/03/ informe-sarampo-25-30ut18.pdf 
12. Ministry of Health $(\mathrm{MoH})$. Brazil. Secretaria de Vigilância em Saúde. Sarampo: Situação Epidemiológica [Ministry of Health Surveillance. Measles: Epidemiological Situation]. Brasília: MoH; 2018. Available from: http://portalms.saude.gov.br/ saude-de-a-z/sarampo-situacao-epidemiologica

13. Pan American Health Organization/World Health Organization (PAHO/WHO). Measles elimination: field guide. Washington, D.C.: PAHO; 2005. Available from: http://www1.paho.org/hq/ dmdocuments/2010/FieldGuide_Measles_2ndEd_e.pdf

14. World Health Organization (WHO). Measles - Brazil: Disease outbreak news 2018. Geneva: WHO; 2018. Available from: https://www.who.int/csr/don/11-june-2018-measles-brazil/en/.

15. Pan American Health Organization / World Health

Organization (PAHO/WHO). PAHO urges rapid increase

in vaccination coverage to stop spread of measles in the Americas 2018. Washington D.C: PAHO; 2018. Available from: https://www.paho.org/hq/index.php?option=com_co ntent\&view=article\&id=14582:paho-urges-rapid-increasein-vaccination-coverage-to-stop-spread-of-measles-in-theamericas \& Itemid $=1926 \&$ lang $=$ en

\section{License and copyright}

This is an open-access article distributed under the terms of the Creative Commons Attribution (CC BY 4.0) Licence. You may share and adapt the material, but must give appropriate credit to the source, provide a link to the licence, and indicate if changes were made.

This article is copyright of the authors or their affiliated institutions, 2019. 